JURNAL PARIS LANGKIS

Jurnal Pendidikan Pancasila dan Kewarganegaraan

Vol.1 Nomor 2, Maret 2021

E-ISSN: $2723-7001$

https://e-journal.upr.ac.id/index.php/parislangkis

\title{
PROSES PEMBELAJARAN DARING PADA MASA PANDEMI COVID-19 DI RODI PGSD FKIP UPR
}

\author{
Asih $^{1}$, Femmy $^{2}$, Nyoto $^{3}$ \\ Pendidikan Guru Sekolah Dasar, Fakultas Keguruan dan Ilmu Pendidikan, Universitas \\ Palangka Raya

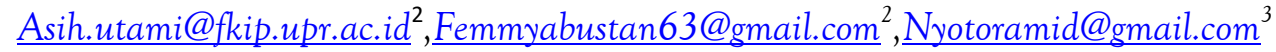

\begin{abstract}
Abstrak:
Pandemi covid-19 yang melanda seluruh negara di dunia termasuk Indonesia memberikan dampak dari semua bidang termasuk bidang pendidikan. Untuk memutus rantai penyebaran covid-19, menteri pedidikan dan kebudayaan mengeluarkan peraturan menteri pendidikan dan kebudayaan no 4 tahun 2020 tentang pembelajaran di era covid 19 terkait belajar dari rumah. Pendidik dan peserta didik dihimbau untuk belajar di rumah dan dari rumah termasuk juga perguruan tinggi. Masalah yang muncul di prodi PGSD FKIP UPR terhadap seruan menteri tersebut adalah masih banyak dosen PGSD yang butuh ditingkatkan kemampuan literasi digitalnya. Masalah lain perlu disoroti saat pembelajaran daring adalah sinyal karena semua mahasiswa kembali ke kampungny amsing-masing sehingga perlu diketahui kendala yang dihadapi untuk itu penelitian ini bertujuan untuk mengetahui proses pembelajaran daring paa masa pandemi covid-19 di prodi PGSD FKIP UPR. Penelitian ini menggunakan pendekatan kualitatif dengan menjelaskan proses pembelajaran daring yang dilaksanakan di prodi PGSD FKIP UPR dengan teknik penyebaran angket secara daring melalui google form dan wawancara. Analisis penelitian menggunakan analisis Miles \& Hubermen yaitu reduksi data,display data dan penarikan kesimpulan data. Proses pembelajaran daring yang terlaksana di prodi PGSD FKIP UPR pada semester ganjil 2020/2021 jika dilihat dari segi persiapan pembelajaran dapat disimpulkan bahwa berdasarkan pendapat mayoritas mahasiswa PGSD dapat dikatakan seluruh dosen sudah melaksanakan pembelajaran daring. Pembelajaran daring yang dilakuakn melalui pembelajaran syncronous dan asyncronous. Platform pembelajaran daring yang digunakan
\end{abstract}

\section{Paris Langkis}

Vol.1 Nomor 2, Maret 2021 
dosen PGSD adalah google meet, zoom, google classroom dan whatsapp.Pada saat pelaksanaan pembelajaran daring, berdasarkan pendapat mayoritas mahasiswa PGSD dapat disimpulkan bahwa seluruh dosen sudah hadir dalam perkuliahan, memberikan materi dan tugas dan juga melakukan penilaian terhadap tugas yang diberikan. Kendala yang dihadapi mahasiswa saat pelaksanaan pembelajaran daring yang paling dominan adalah jaringan internet yang tidak stabil, keterbatasan kuota internet dan menumpuknya tugas dari setiap mata kuliah.Hal utama yang menjadi pendukung keterlaksanaan pembelajaran daring adalah tersedianya bantuan paket data internet untuk pembelajaran dsring akan tetapi bantuan ini ternyata belum sampai pada seluruh mahasiswa PGSD UPR sampai saat ini. Pembelajaran daring yang menyenangkan dan bermakna menurut mahasiswa PGSD adalah pembelajaran daring yang menggunakan syncronous dan asyncronous yaitu memadukan pembelajaran interaktif dan non interaktif seperti mengguankan zoom/google meet dan juga google classroom.

Kata Kunci : proses pembelajaran, pembelajaran daring, covid-19

\section{Abstract:}

The Covid-19 pandemic that hit all countries in the world including Indonesia had an impact on all fields including the education sector. To break the chain of spreading covid19, the minister of education and culture issued a regulation of the minister of education and culture number 4 of 2020 regarding learning in the Covid 19 era related to learning from home. Educators and students are encouraged to study at home and from home, including from universities. The problem that arose in the PGSD FKIP UPR study program regarding the minister's appeal was that there were still many PGSD lecturers who needed to improve their digital literacy skills. Another problem that needs to be highlighted when learning online is the signal because all students return to their respective villages so it is necessary to know the obstacles faced for this. This study aims to determine the online learning process during the Covid-19 pandemic in the PGSD FKIP UPR study program. This study used a qualitative approach by explaining the online learning process carried out in the PGSD FKIP UPR study program by distributing questionnaires online via google form and interviews. The research analysis used Miles EHubermen's analysis, namely data reduction, data display and data conclusion. The online learning process carried out in the PGSD FKIP UPR study program in the odd semester of 2020/2021 when viewed from the perspective of learning preparation, it can be concluded that based on the opinion of the majority of PGSD students, it can be said that all lecturers have implemented online learning. Online learning is done through syncronous and asyncronous learning. The online learning platform used by PGSD lecturers is google meet, zoom, google classroom and whatsapp. At the time of implementing online learning, based on the opinion of the majority of PGSD students, it can be concluded that all lecturers have been present in lectures, providing material and

\section{Paris Langkis}

Vol.1 Nomor 2, Maret 2021 
assignments and also assessing the assignments given. The most dominant obstacle faced by students when implementing online learning is an unstable internet network, limited internet quota and the accumulation of tasks for each course. The main thing that supports the implementation of online learning is the availability of internet data package assistance for online learning but this assistance apparently it has not arrived at all UPR PGSD students to date. Fun and meaningful online learning according to PGSD students is online learning that uses syncronous and asyncronous, which combines interactive and non-interactive learning such as using zoom / google meet and also google classroom.

Keywords: learning process, online learning, covid-19

\section{A. PENDAHULUAN}

Penyebaran virus corona telah menyebar ke Indonesia, Presiden Republik Indonesia telah mengimbau masyarakat untuk belajar, bekerja, dan beribadah di rumah. Merespon hal tersebut menteri pedidikan dan kebudayaan mengeluarkan peraturan menteri pendidikan dan kebudayaan no 4 tahun 2020 tentang pembelajaran di era covid 19 terkait belajar dari rumah. Mendikbud menekankan kegiatan belajar mengajar di laksanakan dari jarak jauh termasuk di perguruan tinggi.Pembelajaran jarak jauh seperti pembelajaran dalam jaringan (daring) dan luar jaringan (luring) sangat dianjurkan untuk dilakukan sekolah pada saat pandemi Covid-19. Ada sekitar 65 perguruan tinggi di Indonesia yang telah melaksanakan pembelajaran daring dalam mengantisipasi penyebaran Covid-19 (CNNIndonesia, 2020)

Pembelajaran daring merupakan pembelajaran yang menggunakan jaringan internet dengan aksesibilitas, konektivitas, fleksibilitas, dan kemampuan untuk memunculkan berbagai jenis interaksi pembelajaran (Moore, Dickson-Deane, \& Galyen, 2011). Pembelajaran daring merupakan pembelajaran yang menggunakan jaringan internet dengan aksesibilitas, konektivitas, fleksibilitas, dan kemampuan untuk memunculkan berbagai jenis interaksi pembelajaran. Banyak platform yang bisa digunakan untuk pembelajaran daring seperti yang dikutip pada kompas yaitu rumah belajar,meja kita,icando, Indonesia x,Google for education,microsoft office 365,quipper school, ruang guru,zenius,sekolahmu,cisco webex (Ely,2020). Para pendidik dihimbau menggunakan platform yang sudah tersedia baik yang gratis maupun berbayar. Permasalahan yang terjadi di prodi PGSD adalah hampir semua dosen tergolong dosen senior karena dari 25 dosen tetap yang ada hanya 4 dosen yang usianya antara 30-40 tahun. Hal ini membuat literasi digital pada dosen PGSD perlu untuk diteliti untuk mengetahui proses pembelajaran daring yang dilaksanakan. Berdasarkan pengalaman peneliti sebagai dosen PGSD FKIP UPR, beberapa pengetahuan platform pembelajaran daring sudah pernah diberikan dalam pelatihan seperti penggunaan google classoom, google meet,zoom cloud

\section{Paris Langkis}

Vol.1 Nomor 2, Maret 2021 
meeting, akan tetapi untuk penggunaan di lapangan belum diketahui apakah sudah diterapkan atau belum sehingga penelitian ini perlu dilakukan.

Pembelajaran daring tidak hanya dibutuhkan literasi digital yang baik tetapi juga butuh sarana dan prasarana yang mendukung seperti jaringan internet atau kuota internet. Menurut Sadikin dan Halimah (2020) tantangan dalam pembelajaran daring yang dihadapi antara lain lemahnya pengawasan terhadap mahasiswa, kurang kuatnya sinyal di daerah pelosok dan mahalnya biaya kuota. Kendala sinyal dan kuota bisa saja dialami mahasiswa PGSD FKIP UPR karena mahasiswa PGSD FKIP UPR tidak semua bersal dari kota Palangka Raya tetapi juga mahasiswa dari daerah pelosok Kalimantan Tengah yang tidak ada jaringan internet bahkan listrik sehingga perlu diketahui proses pembelajaran daring seperti apa yang sesuai dengan kondisi tersebut.

\section{B. METODE PENELITIAN}

Jenis penelitian yang digunakan adalah penelitian kualitatif. Tujuan penelitian ini adalah menggambarkan pembelajaran daring yang diselenggarakan di Prodi PGSD FKIP Universitas Palangka Raya tahun ajaran 2020/2021 pada semester ganjil. Penelitian ini dilakukan dengan menyebar angket kepada subyek penelitian. Subyek penelitian adalah mahasiswa PGSD FKIP UPR semester 1 sampai 5 dengan jumlah responden 415 mahasiswa. Angket dibuat dalam bentuk google form yang berisi soal angket semi terbuka. Aspek-aspek yang ditanyakan dalam angket adalah: (1) persiapan pembelajaran daring; (2) pelaksanaan pembelajaran daring; (3) kendala saat pembelajaran daring; (4) hal yang mendukung keterlaksanaan pembelajaran daring;(5) refleksi pembelajaran daring. Analisis data penelitian dilakukan menggunakan model analisis Miles \& Huberman (1994) yang terdiri dari tiga tahapan, yaitu reduksi data, display data, serta penarikan dan verifikasi kesimpulan.

\section{HASIL PENELITIAN DAN PEMBAHASAN}

\section{Persiapan Kegiatan Pembelajaran}

Hasil data yang diperoleh melalui angket mengenai platform yang digunakan dosen PGSD dalam melakukan pembelajaran daring bervariasi yaitu google meet, zoom, google clasroom, whatsapp, youtube, medsos (instagram, facebook, twiter), lms FKIP dan sms.

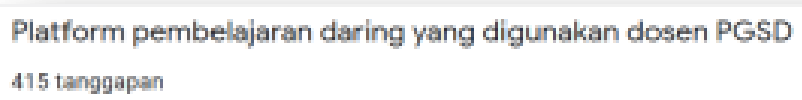




\section{Gambar 1. Platform pembelajaran daring}

Berdasarkan gambar digaram terlihat bahwa google meet adalah platform pembelajaran yang dipakai Dosen PGSD dalam melaksanakan pembelajaran daring. Google meet lebih dipilih karena pada aplikasi ini tidak dibatasi waktu untuk melaksanakan meeting dengan free dan tidak boros kuota. Berikut hasil waancara peneliti dengan salah satu komti kelas tentang platform apa saja yang digunakan dosen PGSD dalam melaksanakan pembelajaran daring.

Peneliti : "Iyaa baik,pertanyaan kedua Platform apa saja yang digunakan dosen untuk melakukan pembelajaran daring ini?"

Komti : "Platform yang digunakan ada whatsapp,zoom,google meet, google classroom, dan youtube bu"

\section{Pelaksanaan Pembelajaran Daring}

Pada kegiatan pembelajaran daring sering terjadi adanya perubahan jadwal karena ada beberapa kendala yang dihadapi dosen misalnya jadwal mengajar bersamaan dengan jadwal ujian skripsi mahasiswa atau seminar proposal atau kegiatan pelatihan lainnya dan kegiatan lain yang tidak memungkinkan dosen melakukan pembelajaran sesuai jadwal yang telah dijadwalkan prodi. Berdasarkan hasil angket mayoritas seluruh mahasiswa menjawab bahwa dosen PGSD memberikan konfirmasi kepada mahasiswa jika ada perubahan jadwal sebanyak 72,5\%, kadang-kadang 24,1\% dan jarang 3,4\%.

Berdasarkan wawancara yang dilakukan peneliti dengan komti kelas dapat diketahui bahwa munculnya jawaban kadang-kadang dan jarang disebabkan ada beberapa dosen yang tidak memberi kabar tentang perkuliahan meskipun sudah diingatkan komti melalui chat di whatsapp atau di telp sehingga komti kelas tidak mengetahui dengan pasti ada perkuliahan atau tidak seperti yang sudah terjadwal. Berikut cuplikan wawancara peneliti dengan komti yang mendukung analisa tentang tidak adanya informasi yang diberikan dosen ketika ada perubahan jadwal.

Peneliti : "okee baik,pertanyaan ketiga Apakah dosen memberikan informasi kepada mahasiswa jika ada perubahan jadwal dalam pelaksanaan pembelajaran?"

\section{Paris Langkis}

Vol.1 Nomor 2, Maret 2021 
Komti : "sering bu,tetapi terkadang ada juga dosen yang tidak merespon sama sekali melainkan hanyamembacapesan saja lalu kami para mahasiswa kebingungan harus melakukan apa ,lalu terjadi miskomunikasi lalu tidak masuk.

Pertanyaan pada soal angket selanjutnya adalah tentang kehadiran dosen dalam perkuliahan daring. Berdasarkan hasil angket diperoleh data bahwa dosen PGSD selalu hadir dalam perkuliahan daring sesuai jadwal yang telah disepakati adalah jawaban paling dominan dari responen yaitu mencapai 58,6\%, selanjutnya adalah pendapat yang menyatakan bahwa dosen PGSD kadang-kadang hadir dalam perkuliahan sesuai jadwal yang telah disepakati sebanyak $40 \%$ dan sisanya menjawab jarang yang artinya dosen PGSD jarang hadir pada perkulihan daring sesuai jadwal yang telah disepakati.

Berdasarkan hasil wawancara yang dilakukan pada seluruh komti semester satu sampai semester lima diketahui bahwa mahasiswa yang menjawab kadang-kadang dan jarang yang artinya dosen PGSD kadang-kadang atau jarang masuk pada perkuliahan sesuai jadwal karena ada beberapa dosen yang tidak hadir sesuai jadwal dan ada juga yang hanya hadir di akhir pertemuan saja.

Pada pelaksanaan pembelajaran daring kehadiran dosen sangat diperlukan karena dengan adanya Dosen yang hadir akan memberikan semangat dan motivasi bagi mahasiswa untuk belajar, selain itu biasanya dosen akan memberikan materi yang akan disampaikan dalam pembelajaran meskipun secara daring. Pada soal angket juga terdapat poin yang membahas tentang peran dosen dalam memberikan materi. Berdasarkan hasil angket diperoleh data bahwa dosen selalu memberikan materi perkuliahan sesuai rencana perkuliahan semester yang telah disusun. Berikut data hasil angket tentang ada atau tidaknya materi yang diberikan dosen saat perkulihan dengan pembelajaran daring

Dosen memberikan materi perkuliahan sesuai dengan rencana perkuliahan semester (sesuai dengan RPS)

415 tanggapan

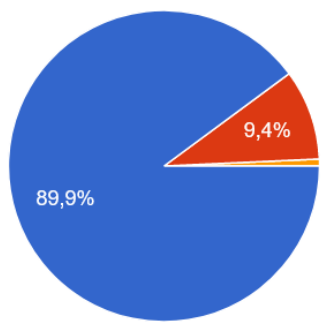

Gambar 2. Diagram Tentang Pemberian Materi

\section{Paris Langkis}

Vol.1 Nomor 2, Maret 2021 
Berdasarkan diagram lingkaran tersebut dapat diketahui bahwa mahasiswa yang menjawab selalu mendominasi jawaban yaitu 89,9 \% dan 9,4\% mahasiswa menjawab kadang-kadang. Hasil angket kemudian dibandingkan dengan hasil wawancara. Berdasarkan hasil wawancara diperoleh penjelasan bahwa ada jawaban kadang-kadang muncul dari mahasiswa dikarenakan ada bebrapa dosen yang saat mengajar daring tidak memberikan materi tetapi hanya memberikan tugas saja.

Pada saat penyampaian materi ada banyak beragam bentuk penyampaian materi yang diberikan terkhusus pada saat pandemi covid-19. Hasil angket menunjukan bahwa power point atau PPT merupkan bentuk materi yang paling dominan dilakukan dosen PGSD. Secara garis besar bentuk materi yang disampaikan dosen PGSD pada mahasiswa terdapat pada grafik berikut.

Bentuk materi yang diberikan dosen saat pembelajaran daring

415 tanggapan

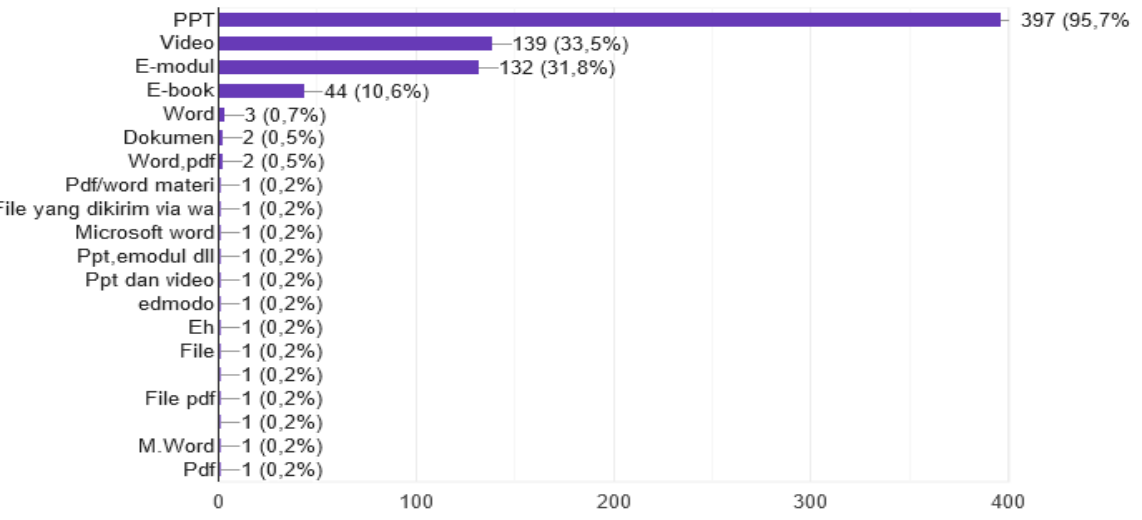

Gambar 3. Diagram Tentang Bentuk Materi Yang Diberikan Dosen

Pada proses pembelajaran terutama pembelajaran daring tentunya pemberian tugas dapat membantu dosen untuk mengetahui pemahaman mahasiswa tentang materi yang diajarkan. Hasil angket diperoleh data bahwa dosen PGSD selalu memberi tugas saat perkuliahan pada pembelajaran daring sebanyak 59,3\% dan dosen PGSD kadang-kadang memberi tugas pada saat perkuliahan daring adalah 39,8\%. Berdasarkan hasil wawancara, dapat diketahui tidak semua dosen pada setiap perkuliahan memberikan tugas dikarenakan ada dosen yang memberikan tugas atau latihan soal hanya pada pertemuanpertemuan tertentu saja.

Tugas ataupun latihan soal yang diberikan dosen kepada mahasiswa seharusnya dikembalikan lagi kepada mahasiswa setelah dikoreksi atau dinilai

\section{Paris Langkis}

Vol.1 Nomor 2, Maret 2021 
agar mahasiswa mendapat balikan dari apa yang telah mereka kerjakan. Hasil angket menunjukan bahwa menurut jawaban yang paling banyak dipilih mahasiswa yaitu dosen selalu melakukan penilaian terhadap tugas yang diberikan.

Dosen melakukan penilaian / assesmen terhadap tugas yang diberikan 415 tanggapan

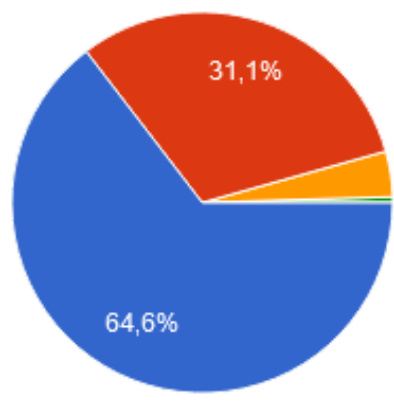

Selalu

Kadang-kadang

Jarang

Tidak pernah

Gambar 4. Penilain Terhadap Tugas

\section{Kendala Saat PelaksanaanPembelajaran Daring}

Pada saat pembelajaran daring sering terjadi kendala. Berdasarkan hasil angket kendala utama yang dihadapi mahasiswa saat pembelajaran daring adalah jaringan internet yang tidak stabil, keterbatasan kuota internet dan menumpuknya tugas dari setiap mata kuliah. Berikut data hasil angket tentang kendala yang dihadapi mahasiswa saat pembelajaran daring.

Ketersediaan jaringan internet merupakan kendala saat melaksanakan pembelajaran daring 415 tanggapan
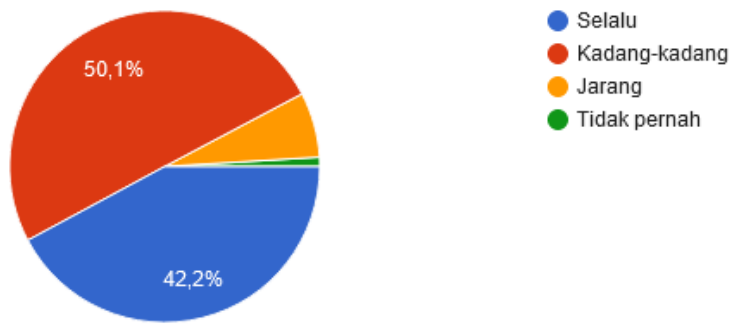

Gambar 5. Kendala Jaringan Internet

\section{Paris Langkis}

Vol.1 Nomor 2, Maret 2021 
Berdasarkan hasil wawancara antara peneliti dan komti, kendala yang dihadapi saat pembelajaran daring adalah jaringan internet yang tidak stabil karena sebagian mahasiswa sudah pada pulang kampung yang susah signal internet di daerahnya sehingga ada beberapa mahasiswa yang saat melaksankan perkuliahan harus naik ke daerah yang tinggi untuk mencari signal. Kendala berikutnya berdasarkan hasil wawancara adalah keterbatasan kuota internet karena sebagian besar mahasiswa menggunakan kuota internet pribadi saat perkuliahan daring. Pembelajaran daring yang menggunakan aplikasi meeting membutuhkan kuota yang besar untuk mengikuti perkuliahan sehingga mahasiswa harus mengeluarkan dana tersendiri untuk membeli paket data internet. Berikut data hasil angket yang menunjukan pengeluaran rata-rata perbulan mahasiswa dalam membeli kuota internet.

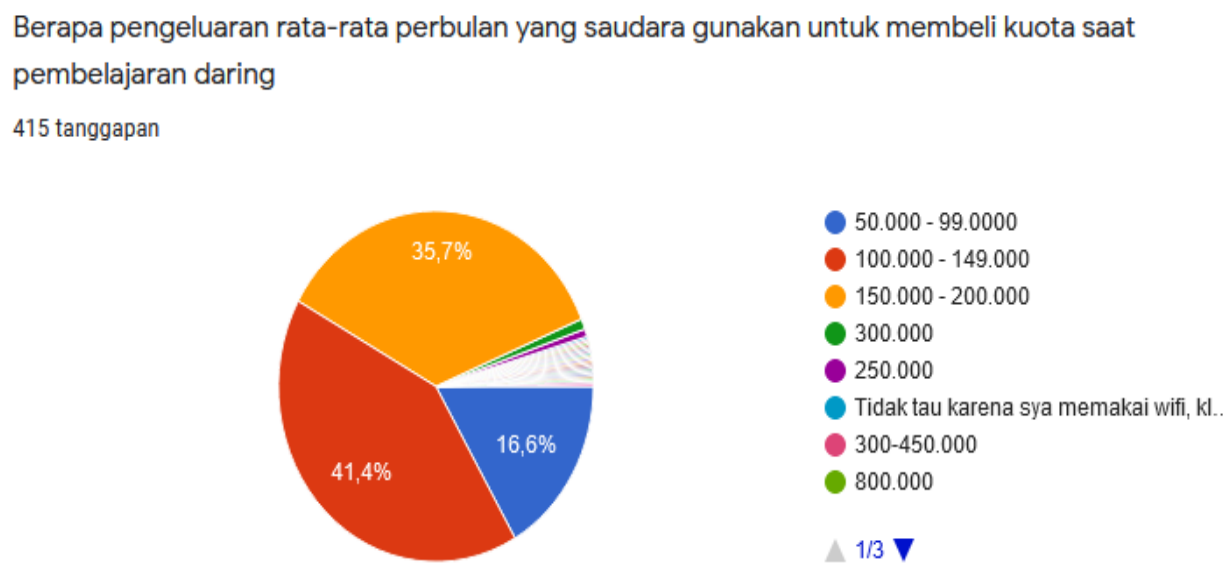

$50.000-99.0000$

$100.000-149.000$

$150.000-200.000$

300.000

250.000

Tidak tau karena sya memakai wifi, kl.

$300-450.000$

800.000

$\Delta 1 / 3 \boldsymbol{\nabla}$

Gambar 6. Pengeluaran Rata-Rata Untuk Membeli Kuota

Penguasaan TIK hanya kendala kecil yang dihadapi sebagian mahasiswa. Sebagian besar mahasiswa mampu menguasai TIK dengan baik. Berdasarkan hasil angket, hanya 13,5\% mahasiswa saja yang memiliki kendala dengan penguasan TIK seperti pada diagram berikut.

\section{Paris Langkis}


Apakah penguasaan TIK (teknologi informasi dan komunikasi) menjadi kendala dalam

pembelajaran daring?

415 tanggapan
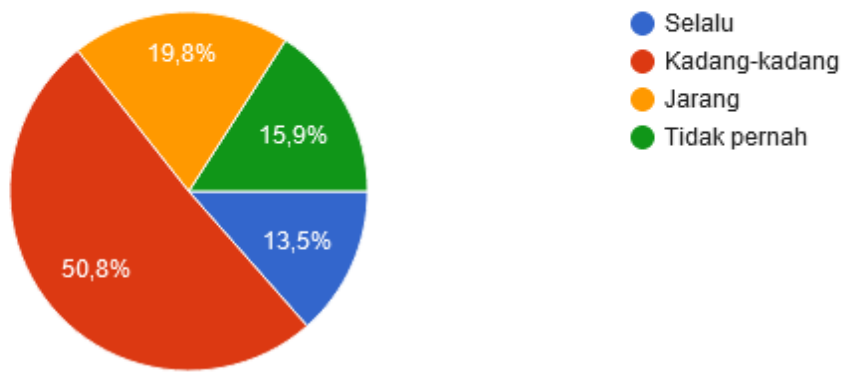

Gambar 7. Kendala Penguasaan TIK

\section{Hal Pendukung Keterlaksanaan Pembelajaran Daring}

Kendala utama yang dihadapi mahasiswa adalah keterbatasan kuota internet sehingga yang menjadi solusi atas kendala tersebut adalah adanya bantuan kuota internet. Berdasarkan penjelasan sekretaris jendral kemendikbud, Ainun Naim, bantuan kuota data internet diberikan kepada siswa, mahasiswa, guru, serta dosen. Bantuan kuota internet untuk mahasiswa dan dosen adalah 50 GB per bulan akan tetapi sampai saat ini belum ada realisasinya pada mahasiswa PGSD UPR. Berdasarkan hasil wawancara peneliti dengan komti kelas, pada awal perkuliahan memang mahasiswa diminta mengisi data untuk diajukan sebagai mahasiswa yang mendapat bantuan kuota internet akan tetapi sampai saat ini masih belum ada. Berikut cuplikan hasil wawancara antara peneliti dengan komti kelas.

Peneliti : "Okee kuota ya, apakah kamu sudah mendapatkan bantuan paket data untuk perkuliahan daring ini dari kemendikbud?'

Komti : "sejauh ini belum ada masuk ke saya bu bantuan tersebut, jadi saya belum mendapatkan nya bu. Di awal perkuliahan memang ada kami diminta TU untuk mengisi data tentang itu tapi sampai sekarang belum ada."

Hal lain yang mendukung pembelajaran daring terlaksana adalah kelonggaran pengumpulan tugas yang diberikan dosen sehingga mahasiswa bisa merencanakan waktu untuk mengupload tugas bagi yang terkendala jaringan intenet.

\section{Refleksi Pembelajaran Daring}

\section{Paris Langkis}

Vol.1 Nomor 2, Maret 2021 
Pada masa pandemi covid-19 ini pembelajaran di UPR dianjurkan untuk dilaksanakan secara daring. Ketua Prodi PGSD meminta seluruh dosen agar melaksanakan pembelajaran secara daring. Berdasarkan pembahasan mengenai kendala yang dihadapi mahasiswa saat pembelajaran daring, ternyata kendaka tersebut membuat pembelajaran daring menjadi tidak efektik. Berikut data hasil angket yang menunjukan bahwa sebagian besar mahasiswa PGSD berpendapat bahwa pembelajaran daring kurang efektif dalam memahami konsep materi saat perkuliahan.

\section{Pembelajaran daring efektif untuk memahami konsep materi yang dipelajari \\ 415 tanggapan

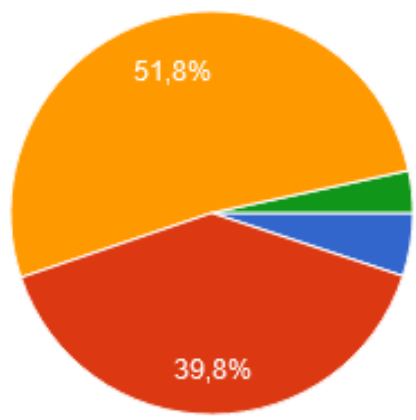 \\ Sangat efektif \\ Efektif \\ Kurang efektif \\ Tidak efektif}

Gambar 8. Tanggapan Responden TentangKeefektifan Pembelajaran daring

Data ini juga didukung dengan hasil wawancara antara peneliti dengan komti yang menyatakan hal yang sama tentang ketidakefektifan pembelajaran daring.

Peneliti : " iyaa mungkin itu selalu jadi permalasahan mahasiswa saat ini ya, selanjutnya apakah kamu merasa pembelajaran daring ini efektif untuk dapat memahami konsep materi yang dipelajari?"

Komti : Menurut saya kurang efektif Bu tapi apa boleh buat keadaan memaksa kita agar daring seperti ini Bu"

\section{KESIMPULAN DAN SARAN}

\section{1) Kesimpulan}

1. Pembelajaran daring yang dilakuakn melalui pembelajaran syncronous dan asyncronous. Platform pembelajaran daring yang digunakan dosen PGSD adalah google meet, zoom, google classroom dan whatsapp. Tidak semua dosen PGSD melaksnakan pembelajaran daring sesuai jadwal yang telah disusun

\section{Paris Langkis}

Vol.1 Nomor 2, Maret 2021 
prodi PGSD akan tetapi berdasarkan pendapat mayoritas mahasiswa PGSD, dosen memberikan informasi jika ada perubahan jadwal perkuliahan.

2. Pada saat pelaksanaan pembelajaran daring, berdasarkan pendapat mayoritas mahasiswa PGSD dapat disimpulkan bahwa seluruh dosen sudah hadir dalam perkuliahan, memberikan materi dan tugas dan juga melakukan penilaian terhadap tugas yang diberikan.

3. Kendala yang dihadapi mahasiswa saat pelaksanaan pembelajaran daring yang paling dominan adalah jaringan internet yang tidak stabil, keterbatasan kuota internet dan menumpuknya tugas dari setiap mata kuliah.

4. Hal utama yang menjadi pendukung keterlaksanaan pembelajaran daring adalah tersedianya bantuan paket data internet untuk pembelajaran akan tetapi bantuan ini ternyata belum sampai pada seluruh mahasiswa PGSD UPR sehingga mereka harus mengeluarkan kebutuhan tambahan untuk pembelajaran. Pembelajaran daring juga dapat terlaksana karena dosen memberikan kelonggaran waktu dalam mengumpulkan tugas.

5. Hasil refleksi yang dilakukan oleh mahasiswa dapat disimpulkan bahwa pembelajaran daring kurang efektif untuk perkuliahan saat pandemi in karena mahasiswa kurang memahami materi yang diajarkan dengan pembelajaran daring. Pembelajaran daring yang menyenangkan dan bermakna menurut mahasiswa PGSD adalah pembelajaran daring yang menggunakan syncronous dan asyncronous yaitu memadukan pembelajaran interaktif dan non interaktif seperti mengguankan zoom/google meet dan juga google classroom.

2) Saran

Berdasarkan kesimpulan sebagaimana tersebut di atas, maka dapat disarankan agar:

1. Diharapkan prodi mengevaluasi keterlaksanaan bantuan paket data internet untuk mahasiswa agar bisa mendukung keterlaksanaan pembelajaran daring

2. Dosen PGSD lebih memaksimalkan lagi keterlaksanaan pembelajaran daring

3. Dosen PGSD lebih kreatif dan bervariasi metode pemeblajaran daring yang dilaksanakan agar pembelajarn menyenangkan dan bermakna

\section{DAFTAR PUSTAKA}

CNN Indonesia. (n.d.-b). 65 Kampus Kuliah dari Rumah, Sultan Yogya Ragukan Efektivitas. Retrieved from https://www.cnnindonesia.com/nasional/20200316110707-20483756/65-kampus-kuliah-dari-rumah-sultan-yogya-ragukan-efektivitas

Miles, M. B., \& Huberman, M. (1994). Qualitative Data Analysis Second Edition.SAGE Publications.

\section{Paris Langkis}

Vol.1 Nomor 2, Maret 2021 
Moore, J. L., Dickson-Deane, C., \& Galyen, K. (2011). E-Learning, online learning, and distance learning environments: Are they the same? Internet and Higher

Rosali,Ely Setiyasih. 2020. Aktifitas pembelajaran daring pada masa pandemi covid19 di jurusan pendidikan geografi Universitas Siliwangi. Geography Science Education Journal Vol. 1 No.1

Sadikin dan Hamidah. 2020. Pembelajaran daring di tengah wabah covid-19. Jurnal Ilmiah Pendidikan Biologi Vol.6 No.2 hal 212-224

Sugiyono. (2014). Memahami Penelitian Kualitatif. CV Alfabeta. 